\title{
Seasonal dynamics and primary production of the flora in a winter rye field in Finland
}

\author{
PÄIVI HALINEN and MIKKO RAATIKAINEN \\ Department of Biology, University of Jyväskylä, Yliopistonkatu 9, \\ 40100 Jyväskylä, Finland
}

\begin{abstract}
The total weed seed storage in the plough layer of $20 \mathrm{~cm}$ was $93965 \mathrm{seeds} / \mathrm{m}^{2}$, of which 36 taxa were defined. The proportion of seeds of annual and winter annual species in soil was $89.6 \%$. The number of rye seeds emerging in autumn was 614 per $\mathrm{m}^{2}$ and weeds 224 per $\mathrm{m}^{2}$. The total number of weeds was $381 / \mathrm{m}^{2}$ when the calculation was based on the time of maximal appearance. $0.3 \%$ of the total amount of weeds emerged.

Rye and Elymus repens were the dominant species in the above-ground vegetation, whereas the biomass of the other weeds remained poorly developed because of marked shading from these two.

The maximum biomass of the living above-ground vegetation, $614 \mathrm{~g} / \mathrm{m}^{2}$, was achieved in the middle of August (12.VIII). Net above-ground primary production, measured by the harvesting method, was $664 \mathrm{~g} / \mathrm{m}^{2}$. year and underground production $190 \mathrm{~g} / \mathrm{m}^{2} \cdot$ year, giving a total production of vegetation and detritus of $854 \mathrm{~g} / \mathrm{m}^{2} \cdot$ year. The net efficiency of the primary producers was $0.7 \%$.
\end{abstract}

Index words: weed primary production, winter rye, seasonal dynamics

\section{Introduction}

A weed study on winter cereals in Finland was started in 1969 by the Agricultural Research Centre, and was carried out at the Department of Biology, University of Jyväskylä, and the Institute of Plant Husbandry of the Agricultural Research Centre in Jokioinen. So far a report on weed species and densities (RAATIKAINEN et al. 1979 a), a report on weed biomass (RAATIKAINEN et al. 1985) and two papers on the ecology of weeds over the whole country have been published (RAATIKAINEN \& RAATIKAINEN 1979 b, 1983). This part of the work is concerned with seasonal dynamics and primary production.

Earlier work on this topic includes that of SALONEN (1949) in Finland on the location of roots of rye and BRAY (1963) in Canada on the production of the roots of rye. In Poland, 
Herbich (1969), KuKIELSKA (1973) and WoJCIK (1973) have studied primary production in a winter rye field and PASTERnAK (1974) that in a winter wheat field.

\section{The rye field}

The rye field studied, of area 1.4 ha, was under normal cultivation and was located within a field area of 20 ha in the rural commune of Jyväskylä $\left(62^{\circ} 16^{\prime} \mathrm{N}, 25^{\circ} 33^{\prime} \mathrm{E}\right)$. A $30 \times 100 \mathrm{~m}$ rectangule was studied in the centre of the rye field. The field has been cultivated for over a hundred years. Oats was grown in it in 1970-72, barley in 1973-74 and it was left fallow in 1975. Rye (cv. Pekka) was sown late that autumn, on 13.IX 1975, at a density of $200 \mathrm{~kg} / \mathrm{ha}$.

The soil is sandy till, the results of fertility tests performed in 1975 being: $\mathrm{pH} 5.9$, calcium $1275 \mathrm{mg} / \mathrm{l}$, potassium $150 \mathrm{mg} / \mathrm{l}$, phosphorus $8.4 \mathrm{mg} / \mathrm{l}$, magnesium $60 \mathrm{mg} / \mathrm{l}$, boron (watersoluble) $0.2 \mathrm{mg} / \mathrm{l}$, copper (acid-soluble) 4.0 $\mathrm{mg} / \mathrm{l}$ and manganese $4.0 \mathrm{mg} / \mathrm{l}$. The amounts of calcium, potassium and phosphorus are given as elements.

Observations made at Jyväskylä airport, 17 $\mathrm{km}$ NNE of the site, were used to summarize weather conditions (Kuukausikatsaus Suomen sääoloihin 1975 and 1976). Mean temperature in September 1975 and May 1976 differed from the long-term means for 1931-1960 by about $+2^{\circ} \mathrm{C}$ and those on June and July 1976 by about $-2^{\circ} \mathrm{C}$. Rainfall in September 1975 and June 1976 was about $30 \mathrm{~mm}$ higher than the means for the corresponding months in 1931-60 and that in October-November 1975 and in May 1976 about $30 \mathrm{~mm}$ lower.

\section{Methods}

\subsection{Seed storage in the $20 \mathrm{~cm}$ surface layer}

The cultivated layer of $20 \mathrm{~cm}$ in ten randomly selected plots was sampled with a soil auger $\left(5 \mathrm{~cm}^{2}\right)$ on $7 . \mathrm{V} 1976$, taking eight samples from each plot. Each set of eight samples were mixed to form one specimen, of which 0.61 was analysed. The material was washed through a series of sieves, the smallest mesh size being $0.21 \mathrm{~mm}$. The mesh size was larger than that used by BRENCHLEY and WARINGTON (1930), but smaller than those of Kropac (1966) and PAatela and Erviö (1971), whose seed separation method was adopted for use here with some modifications. The material remaining on the sieves was dried at $40^{\circ} \mathrm{C}$. The seeds and the organic material were then separated out by immersing them in a solution of $0.17 \mathrm{NaCl} / \mathrm{cm}^{3}$ water.

\subsection{Above-ground vegetation}

Ten permanent sampling sites of size $86.5 \times$ $28.9 \mathrm{~cm}\left(0.25 \mathrm{~m}^{2}\right)$ were selected in the rye field for assessment of the number of plant species, number of sprouts of perennial plants and percentage cover. The number of weeds was counted at each site. Percentage cover was estimated by species on 18.X 1975, 11.V 1976, 5.VI 1976, 29.VI 1976, 23.VII 1976, 12.VIII 1976 and 1.IX 1976. The biomasses were studied on 6.V 1977.

Ten $0.25 \mathrm{~m}^{2}$ randomly selected plots were chosen on each counting date, the aboveground plant material was clipped and the non-living parts of plants lying loose on the ground and easily parted from the plants were collected into a detritus sample.

Plant individuals that had overwintered were marked in spring and their growth was monitored until 5.VI 1976. A $0.25 \mathrm{~m}^{2}$ size of sampling plot has been used earlier by other authors including MuKuLA et al. (1969) when studying spring cereals and HerBICH (1969), WOJCIK (1973) and RAATIKAINEN et al. (1979 a, 1985) studying winter cereals.

The plants were dried at $+35^{\circ}$ and weighed. Mean moisture content was $6.3 \%$ in the dicotyledons, $6.1 \%$ in the monocotyledons and $4.7 \%$ in the detritus. All other results are expressed here in terms of dry weight. The grain yield was determined only in the samples taken on 1.IX 1976.

The energy content of the plants was calculated using the values stated by Herbich 
(1969), $17.5 \mathrm{~kJ} / \mathrm{g}$ dry plant material for rye and $17.3 \mathrm{~kJ} / \mathrm{g}$ for the weeds.

\subsection{Underground parts of the vegetation}

The roots in the same clip plots were sampled with a soil auger, two samples of area $150 \mathrm{~cm}^{2}$ and depth $20 \mathrm{~cm}$ being taken from each plot. Thus 20 root samples were taken on each sampling date. The roots were separated from the soil by the washing method used by TörmäLÃ and RAATIKAINEN (1976), for example.

The depths of the roots were examined on 12.VIII 1976, when samples were taken from $0-20$ and $21-40 \mathrm{~cm} .5 .1 \%$ of the underground biomass existed of the latter depth. The biomass of the underground parts of plants was corrected by reference to this figure.

The biomasses of the underground parts of the plants are again quoted in terms of dry weight. Energy content was calculated using the figure of $16.3 \mathrm{~kJ} / \mathrm{g}$ dry plant material stated by Herbich (1969).

\section{Results}

\subsection{Seed storage in the soil}

The seed storage of the cultivated layer was

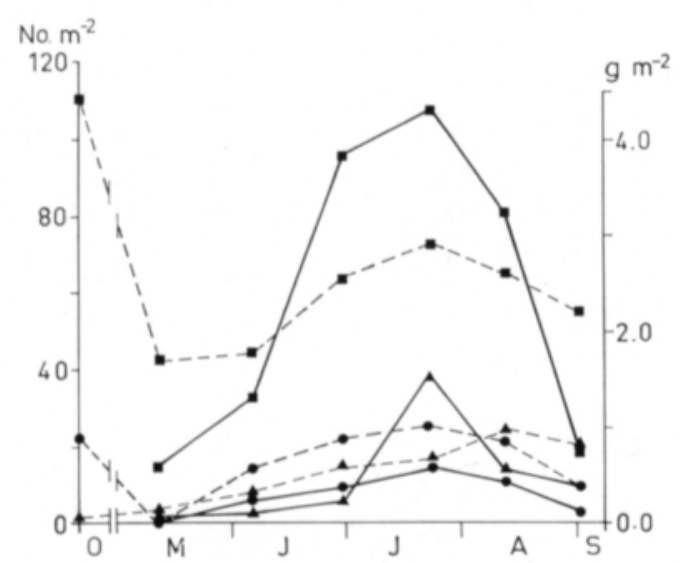

Fig. 1. Seasonal dynamics of the number $(---)$ and the green biomass $(-)$ of winterannuals $(\bullet)$, annuals $(\bullet)$ and perennials ( $\mathbf{\Delta}$ ) (without Elymus repens). Months in figures or text: $\mathrm{O}$ or $\mathrm{X}=$ October. $\mathrm{M}$ or $\mathrm{V}=$ May etc.
93965 seeds $/ \mathrm{m}^{2}$ at the beginning of the growing season (Table 1). 36 taxa were determined to species or genus. The six most abundant taxa, Chenopodium album, Galeopsis spp., Lapsana communis, Spergula arvensis, Stellaria media and Viola arvensis, accounted for $86 \%$ of the total amount of seeds. The proportion of seeds of winter annuals was $46.5 \%$, that of annuals $43.1 \%$, that of perennials $9.5 \%$, that of spring cereals $0.6 \%$ and that of unidentified specied $0.3 \%$.

Rye seed was sown in the autumn to a density of 800 per $\mathrm{m}^{2}$. Germinating percentage was 77 and sprouting percentage 75 .

\subsection{Emergence and wintering}

Of the eight taxa shooting in the autumn, all the individuals of Elymus repens and Poa spp. survived through the winter. $98 \%$ of the individuals of rye wintered successfully, $83 \%$ of those of Viola arvensis, $35 \%$ of those of Lapsana communis and $2 \%$ of those of Stellaria media. All the individuals of Chenopodium album and Galeopsis spp. died during the winter.

Emergence of all the winter annual species continued in spring, but it was considerably less significant than in the autumn. The emergence of annuals was the most rapid in June and that of perennials until August (Fig. 1). Of the winter annual species, rye and Stellaria media were greatest in number in the autumn and the other species only in mid or late summer. Of the annual species, the numbers of Chenopodium album were greatest in the autumn and those of the other annuals generally in June-July. The density of perennials was greatest in the late summer (Table 1). Thus the number of species at the sampling sites increased until August (Fig. 2). The total number of taxa was 30 .

The plant taxa were divided into three groups according to their emergence rhythm:

1) One, more or less clear, emergence period. These species were mainly annuals. Galeopsis spp. and Erophila verna had a very short emergence period with the peak at the 
Table 1. Numbers of seeds in the soil, maximum numbers of individuals of given plant taxa and their timing, and maximum biomass of each taxon and its timing. $\mathrm{w}=$ winter annual or biennial, $\mathrm{a}=$ annual, $\mathrm{p}=$ perennial.

\begin{tabular}{|c|c|c|c|c|c|c|}
\hline & & \multirow{2}{*}{$\begin{array}{c}\text { Seeds } \\
\text { ind. } / \mathrm{m}^{2}\end{array}$} & \multicolumn{2}{|c|}{ Max. number } & \multicolumn{2}{|c|}{ Max biomass } \\
\hline & & & ind. $/ \mathrm{m}^{2}$ & date & $\mathrm{g} / \mathrm{m}^{2}$ & date \\
\hline Rye & & - & 628.0 & $18 . \times 75$ & 501.77 & 23.VII \\
\hline Achillea millefolium & $\mathrm{p}$ & 67 & 1.2 & 1.IX & .11 & 23.VII \\
\hline Agrostis tenuis & $\mathrm{p}$ & 33 & - & - & - & - \\
\hline Avena sativa & a & 67 & - & - & - & - \\
\hline Barbarea vulgaris & w & 433 & - & - & - & \\
\hline Betula spp. & $\mathrm{p}$ & 2233 & - & - & - & - \\
\hline Capsella bursa-pastoris & w & 167 & 1.9 & 1.IX & .08 & $\begin{array}{l}\text { 29.VI, } \\
\text { 23.VII }\end{array}$ \\
\hline Carex canescens & $\mathrm{p}$ & 1667 & - & - & - & - \\
\hline C. echinata & $\mathrm{p}$ & 33 & - & - & - & - \\
\hline C. nigra & $\mathrm{p}$ & 33 & - & & - & - \\
\hline Cerastium fontanum & $\mathrm{p}$ & 667 & .4 & $\begin{array}{l}\text { 12.VIII, } \\
\text { 1.IX }\end{array}$ & .08 & 12.VIII \\
\hline Chenopodium album & $\mathbf{a}$ & 6400 & 22.9 & 18.X.75 & .04 & 29.VI \\
\hline Elymus repens & $\mathrm{p}$ & 100 & 137.6 & 12.VIII & 137.39 & 12.VIII \\
\hline Equisetum arvense & $\mathrm{p}$ & - & - & - & .15 & 23.VII \\
\hline Erophila verna & w & - & 2.4 & 5.VI & .01 & 5.VI \\
\hline Erysimum cheiranthoides & $\mathbf{a}$ & 67 & 6.8 & 23.VII & .02 & 29.VI \\
\hline Fumaria officinalis & a & - & .3 & 12.VIII & - & - \\
\hline Galium spp. & $\mathrm{p}$ & 67 & - & - & - & - \\
\hline Galeopsis spp. & a & 4200 & 9.6 & 5.VI & .28 & 23.VII \\
\hline Gnaphalium uliginosum & a & - & 1.2 & 12.VIII & .20 & 23.VII \\
\hline Hordeum vulgare & a & 533 & - & - & - & - \\
\hline Lapsana communis & w & 11833 & 40.1 & 12.VIII & 3.11 & 23.VII \\
\hline Myosotis arvensis & $\mathbf{w}$ & 900 & 6.0 & 23.VII & .49 & 23.VII \\
\hline Phleum pratense & $\mathrm{p}$ & 500 & 1.7 & 23.VII & .09 & 23.VII \\
\hline Poa spp. & $\mathrm{p}$ & 167 & 5.6 & 12.VIII & .04 & $11 . \mathrm{V}$ \\
\hline Polygonum convolvulus & $\mathrm{a}$ & 267 & - & - & .05 & 12.VIII \\
\hline P. lapahtifolium & $\mathbf{a}$ & 1033 & 2.8 & 23.VIII & .08 & 23.VII \\
\hline Potentilla erecta & $\mathrm{p}$ & 1033 & .4 & $\begin{array}{l}29 . \mathrm{VI} \\
23 . \mathrm{VII} \\
12 . \mathrm{VIII}\end{array}$ & .04 & 12.VIII \\
\hline Ranunculus acris & $\mathrm{p}$ & 267 & - & - & - & - \\
\hline$R$. repens & $\mathrm{p}$ & 133 & 7.6 & 23.VII & .09 & 5.VI \\
\hline Raphanus raphanistrum & a & 800 & 1.2 & 29.VII & .16 & 29.VI \\
\hline Rumex acetosa & $\mathrm{p}$ & 33 & - & - & - & - \\
\hline R. acetosella & $\mathrm{p}$ & 1600 & 2.8 & $\begin{array}{l}\text { 2.VIII, } \\
\text { 1.IX }\end{array}$ & .04 & 23.VII \\
\hline Spergula arvensis & a & 27667 & 6.7 & 23.VII & .03 & 29.VI \\
\hline Stellaria media & w & 24833 & 93.6 & $18 . \times 95$ & .23 & 29.VI \\
\hline Taraxacum spp. & $\mathrm{p}$ & 133 & - & - & - & - \\
\hline Thlaspi arvense & a & - & .8 & 29.VI & .02 & 29.VI \\
\hline Trifolium repens & $\mathrm{p}$ & 33 & 2.4 & 1.IX & .46 & 23.VII \\
\hline Veronica serpyllifolia & $\mathrm{p}$ & 33 & 6.8 & 12.VIII & .19 & 23.VII \\
\hline Vicia cracca & $\mathrm{p}$ & 100 & - & - & .34 & 23.VII \\
\hline Viola arvensis & w & 5567 & 18.4 & 23.VII & .53 & 23.VII \\
\hline Unknown seeds & & 233 & & & & \\
\hline Total seeds & & 93965 & & & & \\
\hline Total weeds & & & 381.2 & & 144.47 & \\
\hline Rye + weeds & & & 1009.2 & & 646.24 & \\
\hline Underground parts & & & & & 886.81 & \\
\hline $\begin{array}{l}\text { Total biomass (above } \\
\text { ground and underground) }\end{array}$ & & & & & 1533.05 & \\
\hline
\end{tabular}




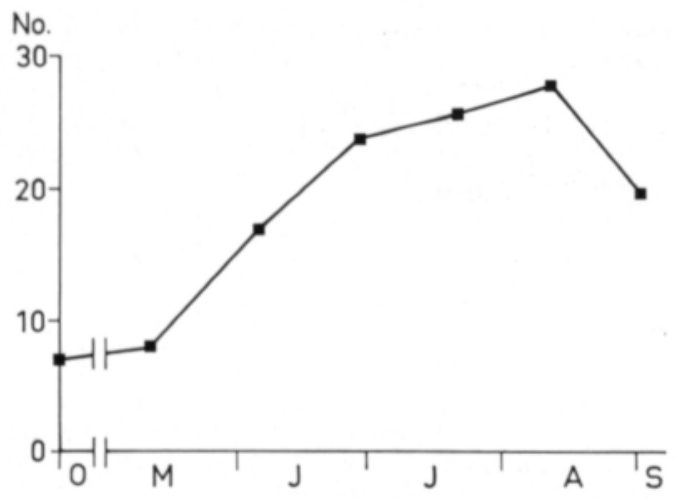

Fig. 2. Number of plant taxa found during sampling intervals.

beginning of June. Spergula arvensis and Erysimum cheiranthoides emerged relatively late, from the end of June until the end of July.

2) A few emergence periods. The species belonging to this group were usually winter annuals. Lapsana communis and Viola arvensis had a three-peaked emergence period, the first peak being in the autumn, the second early in May and the third at the end of June. Among the annual species, this rhythm was most clearly followed by Chenopodium album, the emergence peaks for which were in
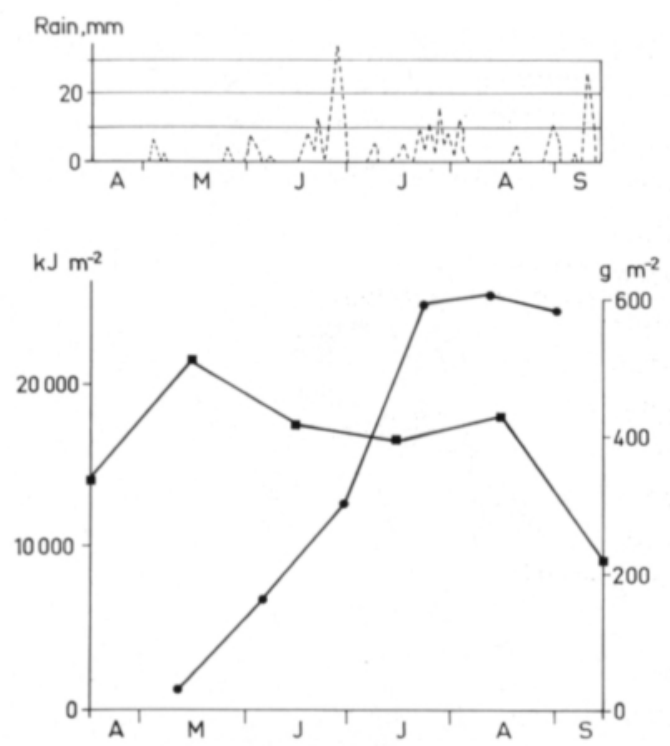

Fig. 3. Seasonal dynamics of total radiation energy (•), green biomass $(\bullet)$ and precipitations $(---)$.

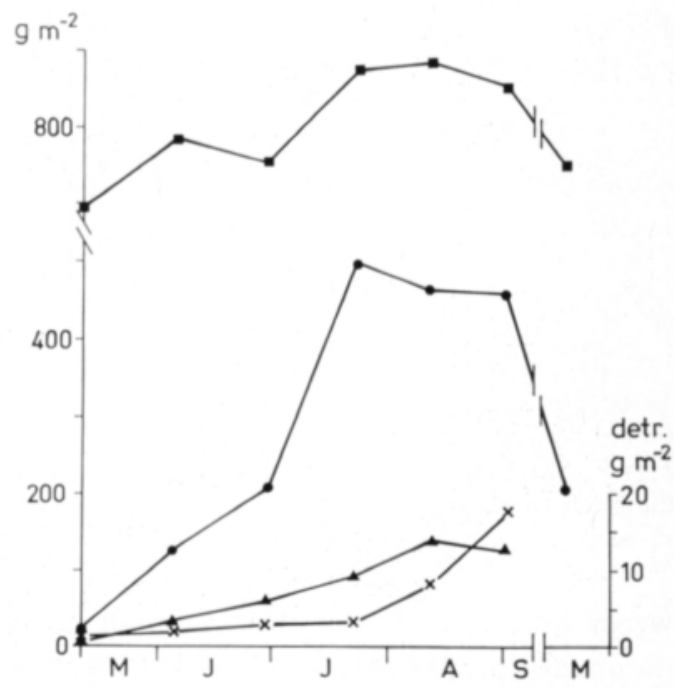

Fig. 4. Seasonal dynamics of the biomass of the main components of vegetations. Rye $(\bullet)$, Underground parts of vegetation $(*)$, Weeds $(\boldsymbol{\Delta})$ and Detritus $(x)$.

the autumn, at the end of May and beginning of June and weak emergence at the beginning of August. Stellaria media had a two-peaked rhythm, the first in the autumn and the second at the end of June. The emergence peaks in autumn and from the end of June to the beginning of August were caused especially by the heavy rain (Fig. 3).

3) Emerging throughtout the growing season. Perennial species were typical representatives of this group, and Myosotis arvensis also emerged fairly evenly from May until the end of July and then on to the end of August after a short break. In the case of certain perennial species, e.g. Elymus repens, an increase in numbers took place almost throughout the growing season due to vegetative growth.

The total number of individuals, shoots and sprouts of weeds was $381 \mathrm{No} . / \mathrm{m}^{2}$ when the calculation was based on the time of maximal appearance of the plants (Table 1). The number of plants to germinate and emerge corresponded to $0.41 \%$ of the total seed storage in the soil, with the mainly vegetatively increasing perennials Elymus repens and Ranunculus repens excluded. The percentage of 


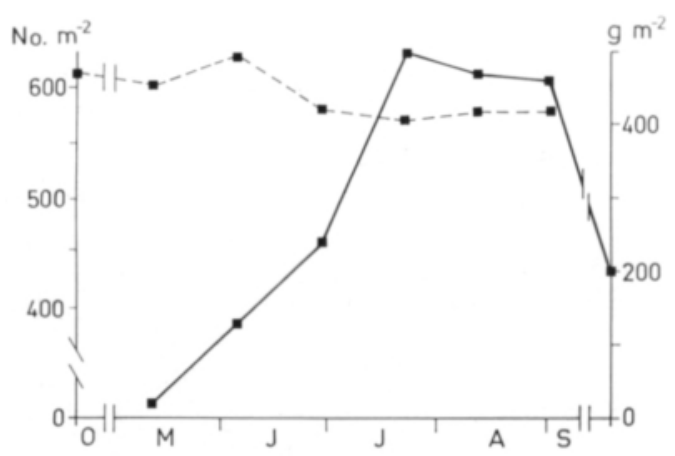

Fig. 5. Seasonal dynamics of the number (---) and the green biomass (-) of rye.

weeds within the total number of plants and number of perennial shoots was $37.8 \%$, and that of sprouts of rye $60.7 \%$.

\subsection{Trends in biomass and numbers of winter rye and weeds}

The biomass of rye and weeds increased up to August (Fig. 4), while the amount of detritus began to increase rapidly after the withering of the plants had accelerated in that month. Detritus reached its maximum in September, $17.5 \mathrm{~g} / \mathrm{m}^{2}$.

The number of rye remained relatively even during the whole growing season apart from a decrease of $7 \%$ in June (Fig. 5).

The winter annual species had already reached their maximum number in autumn, and all of them had their growing season maximum at the end of July. Rye dominated the

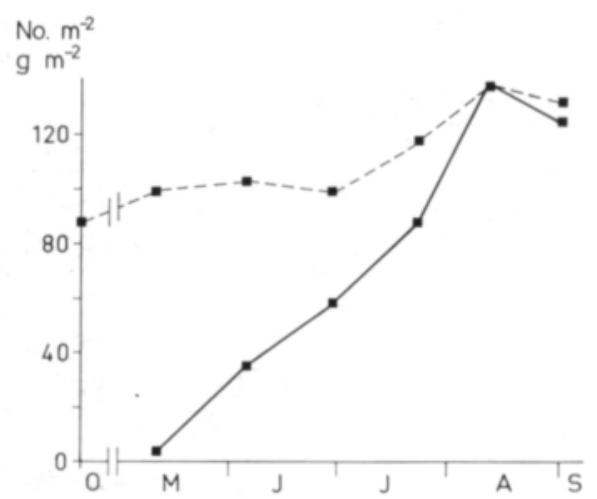

Fig. 6. Seasonal dynamics of the number (---) and the green biomass (-) of Elymus repens.

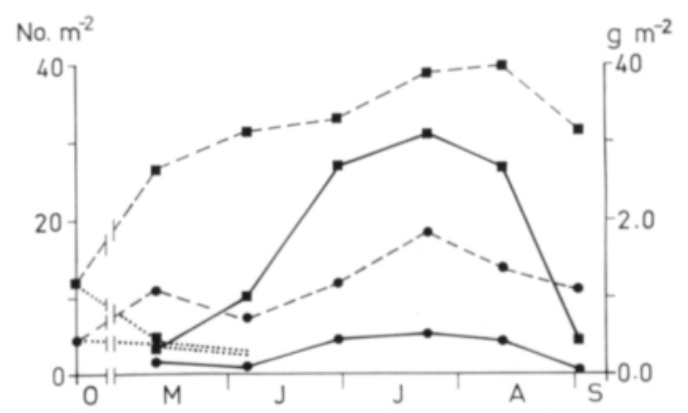

Fig. 7. Seasonal dynamics of the number (---) and the green biomass $(-)$ of Lapsana communis $(*)$ and Viola arvensis $(\bullet)$, (overwintered...).

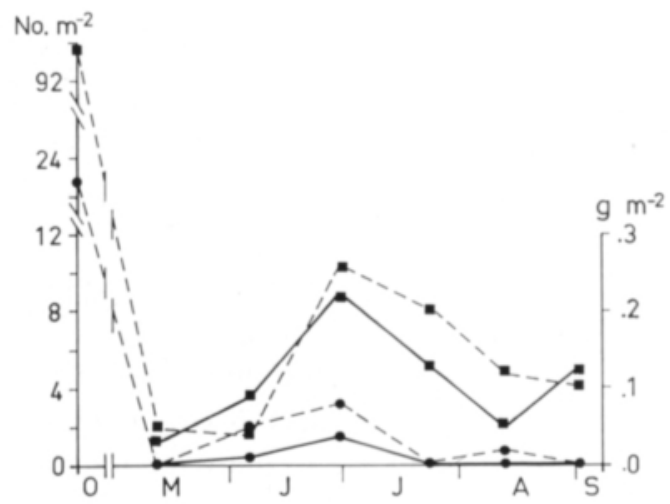

Fig. 8. Seasonal dynamics of the number (-- ) and the green biomass $(-)$ of Stellaria media $(\bullet)$ and Chenopodium album $(\bullet)$.

above-ground biomass, with $75 \%$ its maximum biomass for the whole vegetative period being $84 \%$ at the end of July.

Of the perennial species, Elymus repens was

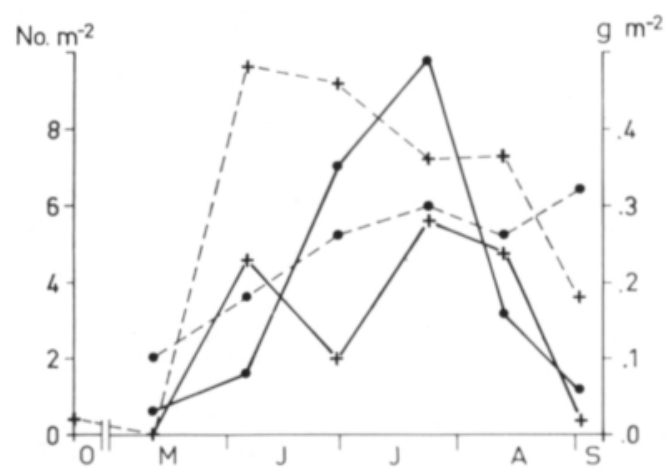

Fig. 9. Seasonal dynamics of the number $(---)$ and the green biomass (-) of Galeopsis spp. (+) and Myosotis arvensis $(\bullet)$. 


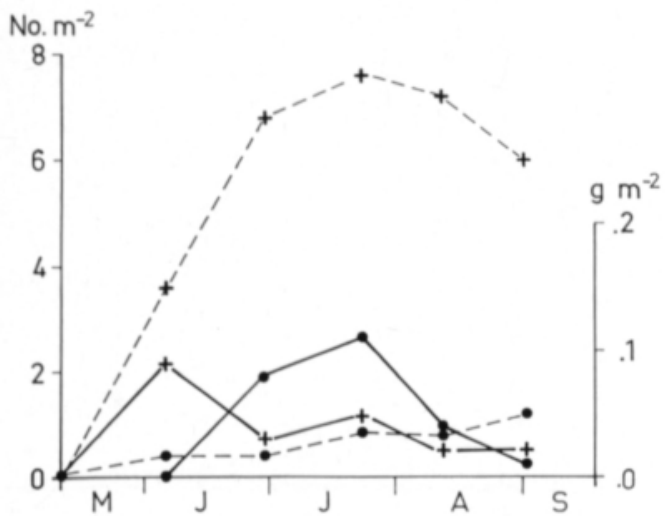

Fig. 10. Seasonal dynamics of the number $(---)$ and the green biomass (-) of Ranunculus repens $(+)$ and Achillea millefolium $(\bullet)$.

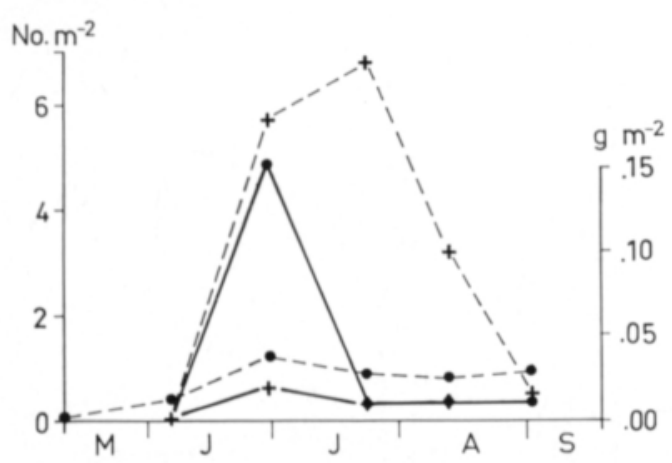

Fig. 11. Seasonal dynamics of the number $(---)$ and the green biomass (-) of Erysimum cheiranthoides $(+)$ and Raphanus raphanistrum $(\bullet)$.

dominant (Table 1), with a growth pattern that resembled that of rye. The maximal biomass increment rate was maintained from the end July until the beginning of August, when the peak biomass was reached (Fig. 6). Typical of the growth of couch grass was the considerable number of vegetative shoots. To facilitate comparison between the winter annuals, annuals and perennials, trends in their numbers and biomasses are presented without rye and $E$. repens in Fig. 1. Weeds other than $E$. repens served only to fill the space left by the strong competitors, rye and $E$. repens, and their individuals were in general small because of the pronounced shading, and with some, notably mainly Galeopsis bifida and Poa pratensis, occurring mainly in sterile form.

Trends in numbers and biomass by taxa

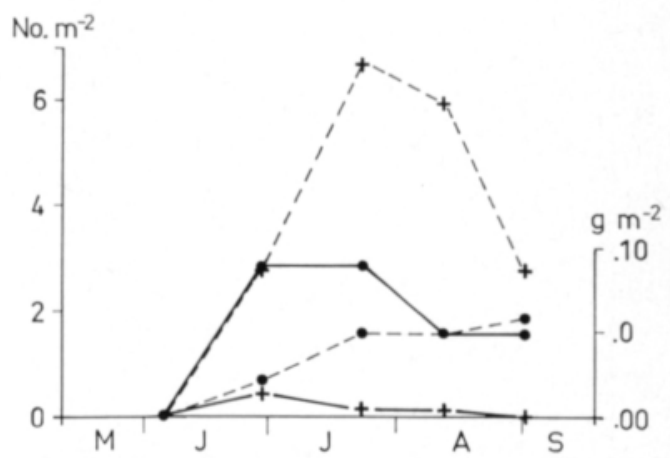

Fig. 12. Seasonal dynamics of the number $(---)$ and the green biomass $(-)$ of Spergula arvensis $(+)$ and Capsella bursa-pastoris (•).

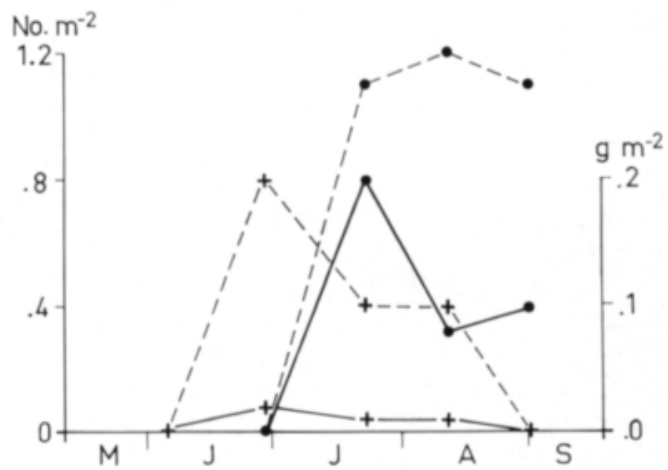

Fig. 13. Seasonal dynamics of the number $(---)$ and the green biomass $(-)$ of Thlaspi arvense $(+)$ and Gnaphalium uliginosum $(\bullet)$.

during the vegetative period are given in Figures $7-13$.

\subsection{Proportional development of plant taxa}

Rye and Elymus repens made up over $83 \%$ of the number of individuals and over $97 \%$ of the biomass of the above-ground vegetation in the rye field during the growing season. Rye and couch grass faced equally well in mutual competition. E. repens continued to emerge and increased its proportion of the biomass after the rye had ripened in August (Figs. 14 and 15).

Practically only $E$. repens among all the weeds succeeded in restricting the growth of rye. Its proportion of the above-ground weed biomass ranged from $86 \%$ to almost $99 \%$. 


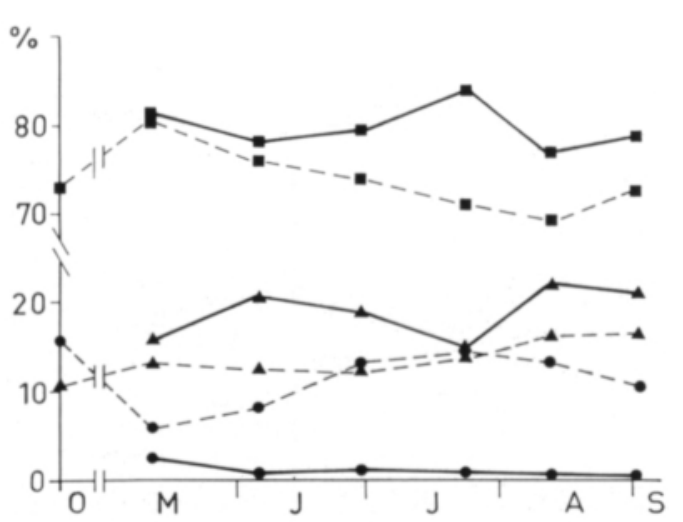

Fig. 14. Seasonal changes in the dominance of the total number $(---)$ and the green biomass $(-)$ of rye $(\bullet)$, Elymus repens $(\boldsymbol{\Lambda})$ and other weeds $(\bullet)$.

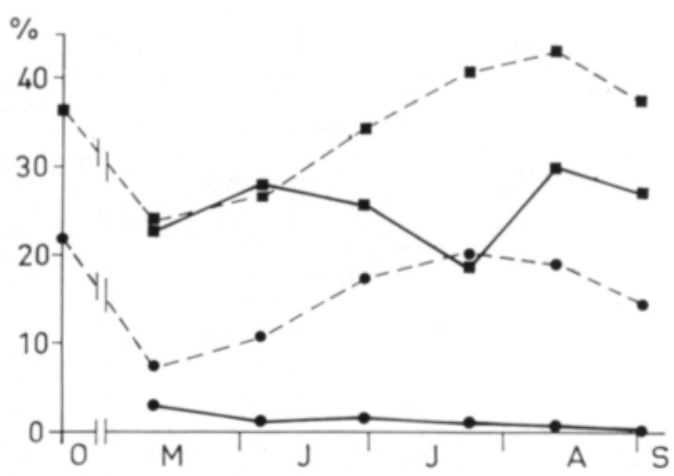

Fig. 15. Seasonal changes in the dominance of the number of rye (-- ) and the biomass of rye (-) of all weeds $(\bullet)$ and of weeds without Elymus repens $(\bullet)$.

The proportion of the biomass composed of winter annuals, annuals and perennials (excluding $E$. repens) decreased as the rye grew, e.g. the biomass of winter annuals from $3 \%$ in May to $0.2 \%$ in August (Fig. 16).

The proportions in terms of numbers of individuals, on the other hand, showed growth within all these groups. The winter annual weeds reached their maximum proportions in autumn, but increased in number during the vegetative period up to the end of July, thus maintaining their position as the biggest group (Fig. 16). Trends in the proportions of annuals and perennials were very similar until July, when that of annuals began to decrease.

Three types of trend in the numbers of the

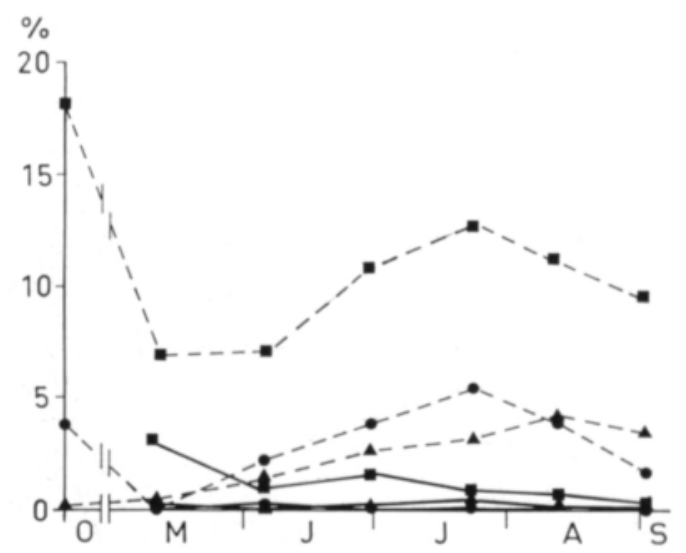

Fig. 16. Proportion of winterannuals (•), annuals ( $\bullet$ ) and of perennials (without $E$. repens $(\mathbf{\Delta})$ of the number $(---)$ and biomass $(-)$ of rye.

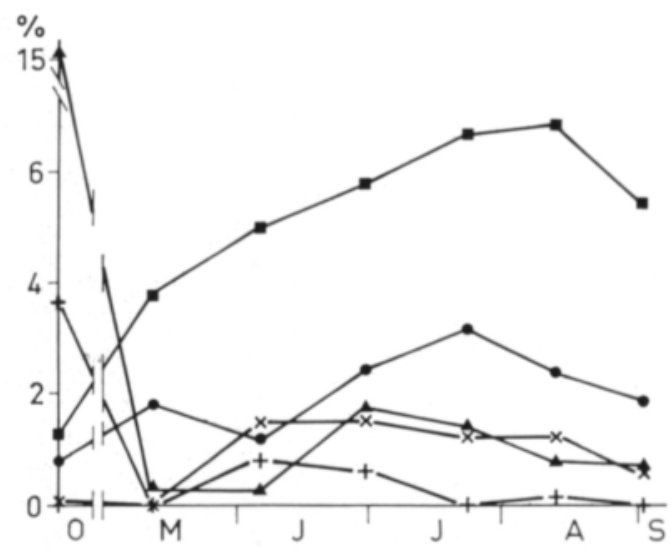

Fig. 17. Proportion of Lapsana communis (•), Viola arvensis $(\bullet)$, Stellaria media ( $\mathbf{\Delta})$, Galeopsis spp. $(\times)$ and Chenopodium album $(+)$ of the number of rye.

different plant taxa could be distinguished in relation to rye:

1) Species that sprouted in the autumn or early in the spring and generally reached their peak either in the autumn or at the beginning of the summer. Among the winter annuals, Viola arvensis belonged to this group, sprouting in the autumn, but not reaching its maximum, $3.2 \%$, until July. Stellaria media and Chenopodium album emerged best in the autumn, the proportion of $S$. media being $15.3 \%$ and that of Chenopodium album $3.7 \%$ (Fig. 17). Of the annual species. Galeopsis spp. emerged early and had already reached its maximum of $1.6 \%$ by June (Fig. 17). 


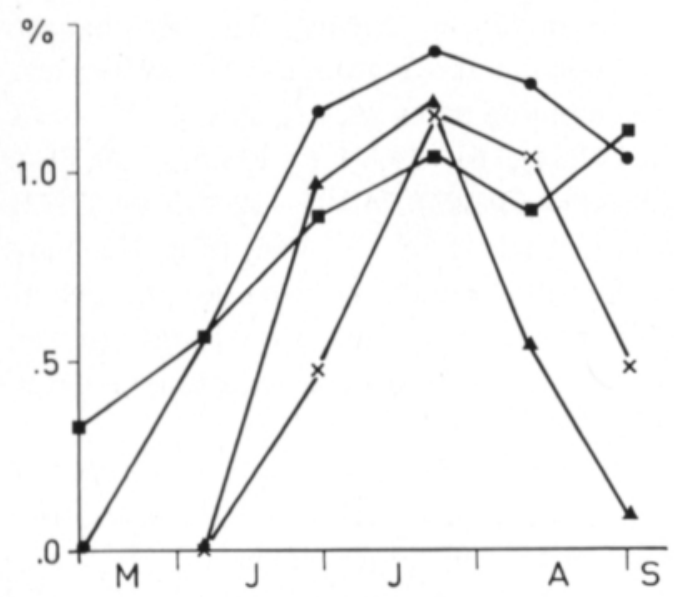

Fig. 18. Proportion of Myosotis arvensis (•), Ranunculus repens $(\bullet)$, Erysimum cheiranthoides $(\boldsymbol{\Delta})$ and Spergula arvensis $(X)$ of the number of rye.

2) Species whose proportion was greatest in midsummer. The sprouts of these could not compete with rye, and soon withered. These were the annuals Erysimum cheiranthoides, maximal $1.2 \%$, Spergula arvensis, $1.2 \%$ and Thlaspi arvense $0.15 \%$, and the perennial Ranunculus repens, $1.3 \%$ (Figs. 18 and 19).

3) Species, which increased in proportion among the total number of individuals during the whole vegetative period and which reached their maximum numbers in AugustSeptember. These included the winter annuals Lapsana communis (Fig. 17) and Myosotis arvensis (Fig. 18), the perennial Achillea millefolium (Fig. 19), and the annuals Raphanus raphanistrum, Capsella bursa-pastoris and Gnaphalium uliginosum (Fig. 19).

\subsection{Primary production}

One method for assessing primary production is to measure the maximal biomass value of the species. The maximum biomass of rye, $502 \mathrm{~g} / \mathrm{m}^{2}$, was attained at the end of July. The calculated energy value of this biomass was $8785 \mathrm{~kJ} / \mathrm{m}^{2}$. The stock of rye grain on the first of September was $170 \mathrm{~g} / \mathrm{m}^{2}$, or $37 \%$ of the concurrent air-dry (humidity $6.1 \%$ ) above-ground biomass of rye. The energy

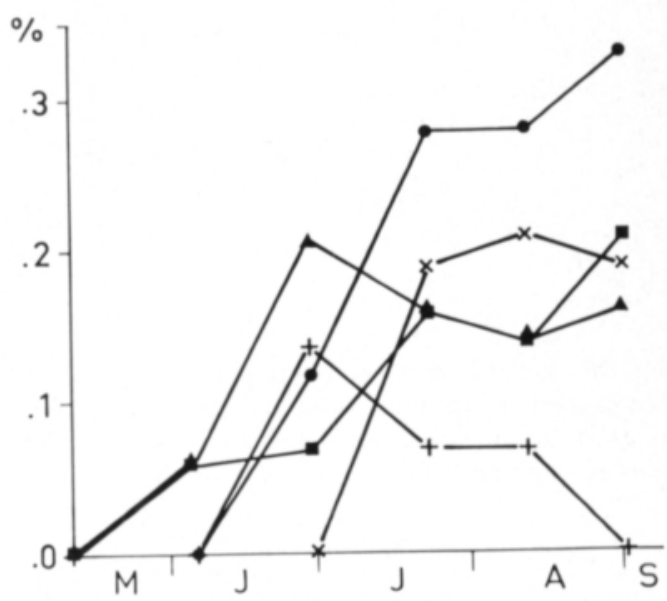

Fig. 19. Proportion of Achillea millefolium (•), Capsella bursa-pastoris $(\bullet)$, Gnaphalium uliginosum $(\times)$, Raphanus raphanistrum $(\mathbf{\Delta})$ and Thlaspi arvense $(+)$ of the number of rye.

value of these grains was $2975 \mathrm{~kJ} / \mathrm{m}^{2}$. The weight ratio between the rye grains and straw was $1: 17$.

The biomass of the stubble after harvesting was $202 \mathrm{~g} / \mathrm{m}^{2}, 3535 \mathrm{~kJ} / \mathrm{m}^{2}$, and this continued to account for a high proportion of the total above-ground biomass, $34 \%$, in the samples taken the next spring (6.V 1977) even though some decomposition had taken place.

The maximum biomass of weeds, $142 \mathrm{~g} /$ $\mathrm{m}^{2}, 2457 \mathrm{~kJ} / \mathrm{m}^{2}$, occurred at the beginning of August. The proportion of the aboveground parts of Elymus repens among total weeds was $97 \%$. Summing of the maximum biomasses of the plant taxa gives an aboveground net primary production of $144.5 \mathrm{~g} /$ $\mathrm{m}^{2}, 2500 \mathrm{~kJ} / \mathrm{m}^{2}$ (Table 1).

The living above-ground biomass reached its peak at the beginning of August (12.VIII), when it was $614 \mathrm{~g} / \mathrm{m}^{2}, 10534.7 \mathrm{~kJ} / \mathrm{m}^{2}$. The net primary production, obtained by summing the maximum biomasses, was $646.5 \mathrm{~g} / \mathrm{m}^{2}$, $11285 \mathrm{~kJ} / \mathrm{m}^{2}$ (Table 1). The proportion of rye was $78 \%$, that of $E$. repens $21 \%$ and that of the other weeds $1 \%$. By adding the maximum value for detritus to the summed value for living above-ground biomass, we obtain a total net above-ground primary production of $664 \mathrm{~g} / \mathrm{m}^{2}, 11554 \mathrm{~kJ} / \mathrm{m}^{2}$. 


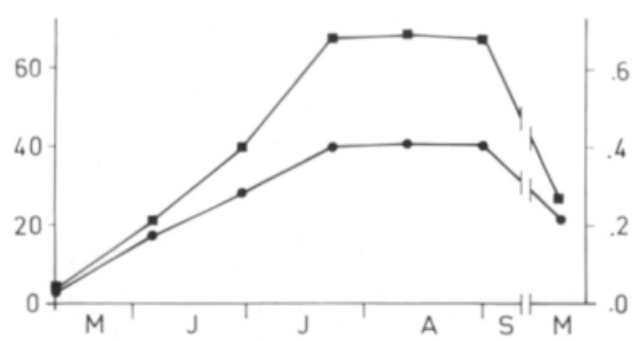

Fig. 20. Relation of the aboveground and underground biomass ( $*$ ) and the proportion of the aboveground biomass of the combined biomass of the underground and aboveground parts $(\bullet)$.

The production of the below-ground vegetation $190.2 \mathrm{~g} / \mathrm{m}^{2}, 3119 \mathrm{~kJ} / \mathrm{m}^{2}$, was obtained by taking the difference between the maximum and minimum biomass values for the growing season. Thus net primary production was 3.2-3.4 times greater than the below-ground biomass itself. The ratio of the green biomass to the below-ground biomass was only 0.7 even at its maximum (12.VIII) and the above-ground biomass never exceeded $41 \%$ of the sum of the below-ground and green biomass during the whole growing season (Fig. 20). Growth of the above-ground biomass was most rapid up to the end of July, after which it continued at a slower rate, until the biomass started to diminish

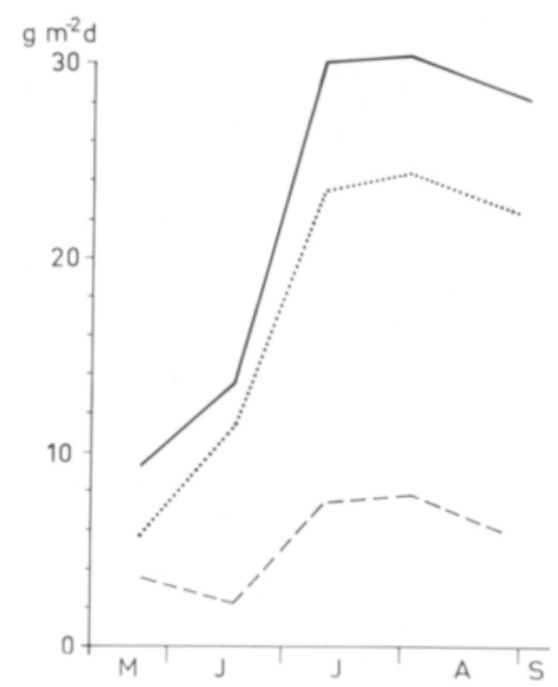

Fig. 21. Daily net changes $\left(\mathrm{g} / \mathrm{m}^{2}\right.$ in green biomass $(\cdots)$, underground biomass $(---)$ and in their sum (-) during sampling interval. in the middle of August. The net changes in the living above-ground biomass between the sampling dates were $\left(\mathrm{g} / \mathrm{m}^{2}\right): 11 . \mathrm{V}-5$.VI $(+142.14), 6 .-29 . \mathrm{VI}(+134.87), 30 . \mathrm{VI}-$ 23.VII (+294.03), 24.VII-12.VIII (+17.92) and 13.VIII-1.IX (-25.66) (Fig. 21). Part of the below-ground biomass decomposed in the early summer, while growth was rapid at the same time and continued until August (Fig. 21).

The sum of the production of the aboveground vegetation, below-ground vegetation and detritus during the period 11.V-1.IX was $853.9 \mathrm{~g} / \mathrm{m}^{2}, 14858 \mathrm{~kJ} / \mathrm{m}^{2}$, taking the vaiue acquired by summing the peak biomasses to obtain a value for above-ground production. Since the total amount of the radiation energy received during the period studied (11.V-1.IX) amounted to $2209733 \mathrm{~kJ} / \mathrm{m}^{2}$, the net efficiency of the primary producers was $0.67 \%$.

\section{Discussion}

\subsection{Number of seeds in the soil}

Research into the amounts of weed seeds in arable soils has mainly employed germination and washing flotation methods, and the differences between the methods used make comparison difficult. The germinations method reveals about $20-25 \%$ of total seed storage in the soil (Kropac 1966). Since the length of dormance and the circumstances of germination differ a lot between different species (KolK 1962), there are also considerable possibilities for error in the results.

Seed storage in the top $20 \mathrm{~cm}$ of the field studied was 93965 seeds $/ \mathrm{m}^{2}$, compared with an average of 43850 seeds $/ \mathrm{m}^{2}$ in the plough layer of $20 \mathrm{~cm}$ reported by PAATELA \& ERVIÖ (1971) in spring cereal fields in Finland. Regional variation was from 30890 seeds/ $\mathrm{m}^{2}$ to 56790 seeds $/ \mathrm{m}^{2}$ and variation due to soil type from 37890 to 53160 seeds $/ \mathrm{m}^{2}$. KROPAC (1966) found 19922 and 70321 seeds $/ \mathrm{m}^{2}$ in $25 \mathrm{~cm}$ layers in two separate lo- 
calities. All the above figures were obtained using the washing-flotation method.

Korsmo (1930) in Norway reported 10500 -33 574 seeds $/ \mathrm{m}^{2}$ in a $25 \mathrm{~cm}$ layer and Brenchley and Warington $(1930,1933)$ in England 39092 and 29330 seeds $/ \mathrm{m}^{2}$ in a 15 $\mathrm{cm}$ layer, both using the germination method.

The weed flora found here consisted mainly of seeds of annual species, which accounted for $89.6 \%$ of total weed storage in the field studied. The proportion of annual weed seeds in arable soils in Switzerland is $81 \%$ (BuCHLI 1936), that in Canada $98.8 \%$ (BudD et al. 1954) and that in Czechoslovakia $92.9 \%$ (Kropac 1966). Moreover, it is usually only a few species that form the majority of the weed seed storage. In this case Spergula arvensis and Stellaria media together contributed $55.9 \%$ of the total number of seeds.

\subsection{Viability and emergence of seeds}

Little research has been carried out into the viability and emergence of seeds in soil. BRENCHLEY \& WARINGTON (1936) in England studied the permanence of seeds in arable soils, and found this to be species specific and to vary mainly from four to nine years and only exceptionally to exceed ten years. In addition to species specificity, many environmental factors such as soil type, climate and cultivation measures influence the retention of viability in seeds.

Although there are great regional and local variations in weed seed storage, certain similarities have also been mentioned. In Czechoslovakia KropaC (1966) reports the number of viable seeds to range from 1000 to 20000 per $\mathrm{m}^{2}$ and in Finland ANISZEwSKI \& SimojoKI (1984) and PALdANIUS \& SiMOJOKI (1984) from 1823 to 64800 seeds $/ \mathrm{m}^{2}$.

Investigations into the germination of seeds are made more difficult by the fact that there are different ages of seeds of the same species in the soil simultaneously. Moreover seeds of some species are known to show variations in their germination process. Van der VEGTE (1978) in Netherlands, for example, identifies two population of Stellaria media in fields within dune areas which differ in their length of dormance, rhythm of germination and the length of life. WEHSARG (1912), BRENCHLEY \& WARINGTON (1930), BuCHLi (1936) \& ERVIÖ (1981) have observed considerable periodicity in the germination of seeds. Moreover it has been discovered that this periodicity can change or weaken along with the age of the seeds (BRENCHLEY \& WARINGTON 1936).

The literature concerning the relation between the potential weed flora (viable seeds) and the number of individuals germinating is mainly based on germination experiments carried out under laboratory conditions, and little work has done on this relation under in vivo conditions. ANISZEWSKI \& SIMOJOKI (1984) and PALDANIUS \& SimoJoKi (1984) report germination of viable seeds to be $10.5-$ $41.9 \%$.

The total number of seeds was determined here in the $20 \mathrm{~cm}$ layer of surface soil. No germination experiments were carried out, but the plant individuals that emerged during the growing period were counted at regular intervals. This information allows partly hypothetical schemes to be formulated regarding the total number of seeds in the soil, the seasonal dynamics of germination.

One of these schemes will be presented here. The germination percentages of the seeds in the $20 \mathrm{~cm}$ plough layer in the different weed groups (winter annuals 43 733, annuals 41033 , perennials 8967 , total 93733) were in the Table 2 .

The germination $\%$ of the totai number of seeds during the whole growing period was $0.5 \%$ for winter annual species, $0.2 \%$ for annuals, $0.4 \%$ for perennials (excluding $E$. repens) and $0.3 \%$ for all species. The result was lower than that reported by PAATELA and ERVIÖ (1971) in a spring cereal field or the proportion of weed seeds emerging in spring cereal fields and numbers of individuals reported by MuKula et al. (1969), 0.6$1.8 \%$.

There may be several reasons for the difference in the proportion of seeds in the soil and 
Table 2. The germination percentages of the seeds in the $20 \mathrm{~cm}$ plough layer.

\begin{tabular}{|c|c|c|c|c|c|c|c|c|}
\hline & $\begin{array}{l}1975 \\
18 . X\end{array}$ & $\begin{array}{l}1976 \\
11 . \mathrm{V}\end{array}$ & $5 . \mathrm{VI}$ & 29.VI & 23.VII & 12.VIII & $1 . I X$ & Total \\
\hline $\begin{array}{l}\text { Winter annuals } \\
\text { germination } \%\end{array}$ & $\begin{array}{c}0.3 \\
/\end{array}$ & 0.1 & $\begin{array}{c}0.01 \\
/\end{array}$ & 0.04 & $\begin{array}{c}0.03 \\
/\end{array}$ & 0.003 & 0.003 & $0.49 \%$ \\
\hline $\begin{array}{l}\text { Annuals } \\
\text { germination } \%\end{array}$ & 0.06 & 0 & 0.04 & 0.03 & 0.02 & 0.003 & + & $0.15 \%$ \\
\hline $\begin{array}{l}\text { Perennials } \\
\text { germination } \%\end{array}$ & 0.01 & 0.02 & 0.1 & 0.1 & 0.04 & 0.1 & 0.01 & $0.38 \%$ \\
\hline $\begin{array}{l}\text { Total } \\
\text { germination } \%\end{array}$ & 0.14 & 0.03 & 0.03 & 0.04 & 0.03 & 0.01 & 0.002 & $0.29 \%$ \\
\hline
\end{tabular}

the numbers of individuals emerging, one possible being a difference in the accuracy of the separating method. The smallest sieve size used by PAATELA \& ERviö (1971) was 0.5 $\mathrm{mm}$, and thus the smallest seeds may have been washed through the sieves, e.g. they did not report any seeds of Veronica.

\subsection{Seasonal rhythm of the vegetation}

Dense stands of rye have been shown in earlier research to be capable of competing successfully with weeds (see MukULA 1964, RAATIKAINEN, RAatiKainen \& TINNILÄ 1971, Erviö 1972, 1978, Pessala 1978), and this was confirmed by the present results with the exception of Elymus repens, which formed a dominant species alongside rye in both numbers and biomass throughout the growing season and was able to compete with it on equal terms (Figs. 5 and 15).

The proportion of other weed species in terms of numbers was greatest, $16.2 \%$, in autumn, before any shading from the rye and couch grass developed, while a second peak, of $14.5 \%$, was recorded on 23.VII, demonstrating that the emergence of weeds had certainly not been choked by these two dominant species even though their growth may have been restricted to a great extent (Fig. 15). ERVІо̆ (1972) similarly notes that a dense spring cereal stand, at least, will reduce yields of weed species to a greater extent than it does their numbers.

Two mortality periods for weed species were observed, in autumn and winter. All the individuals of the annual species that had emerged in the autumn succumbed during the winter, as did $91 \%$ of the winter annuals. Total mortality among the weeds in the course of the winter was $85.5 \%$.

The mean weed density in the field was 206 ind. $/ \mathrm{m}^{2}$, rising to 250 per $\mathrm{m}^{2}$ at its maximum, on 12. VIII. Calculations based on the sum of the maximum values for the different species gave an absolute maximum of 381 ind. $/ \mathrm{m}^{2}$. The figure for the beginning of June, recorded on $5 . \mathrm{VI}$, is $171 \mathrm{ind} . / \mathrm{m}^{2}$, which is lower than that of 303 ind. $/ \mathrm{m}^{2}$ reported by RAATIKAINEN \& RAATIKAINEN (1979 a) for rye fields all over the country at a virtually comparable time of the year, but considerably higher than that of 56 ind. $/ \mathrm{m}^{2}$ quoted by ERvio (1978). This figure for the present field at the beginning of June corresponded to $68 \%$ of the maximum density, which suggests that, employing the same ratio, the maximum density for rye fields throughout the country should be 440 ind. $/ \mathrm{m}^{2}$.

\subsection{Primary production}

All the research made in Poland (Table 3) into the production of winter wheat have been 
carried out using the same plots and consistent cultivation methods, so that the differences in the results can be attributed largely to weather conditions. Herbich (1969) took samples at ten-day intervals throughout the growing season and calculated the primary production of the above-ground vegetation by combining the maximum biomasses of the weeds and rye. The only weed species that he distinguished separately for the purposes of primary production measurements was the dominant species, Apera spicaventi, so that the fact that different species reach their maximum biomass at different times was largely overlooked. KUKIELSKA (1973) and WoJCIK (1973) determined the density and biomass of rye stems on two occassions, the first time when their density was at its maximum in spring and the second immediately after harvesting the grain, and used these figures to calculated the numbers of stems dying before maturing in the course of the growing season. This value was then multiplied by the mean weight of a stem in spring to provide an estimate for the amount of dead organic matter, i.e. detritus, even though no detritus samples were collected at any time.

Samples were collected at regular intervals throughout the growing season in connection with the present work, in order to take the peak biomasses of the various weed species into account when calculating primary production. Here the maximum detritus figure was used throughout to represent the amount of dead organic matter present, in spite of the error introduced by the difficulty of obtaining a reliable estimate for its rate of decomposition. This error cannot be very great, however, especially in an area where the growing season is short.

The lower primary production figure obtained here than in Poland (Table 3) may be due in part to differences between strains (in Poland cv. Wloszanowskie) and partly to geographical and climatic differences in the location of the fields.

One difficulty entailed in the determination of primary underground production is the lack of a suitable method for measuring root mortality, and just the determination of roots to species can cause problems. It is thus common to estimate root production by subtracting the minimum biomass from the maximum biomass, but since this excludes the effects of respiration, consumption by animals and plant diseases and mortality, the result will be

Table 3. Primary production figure obtained by different authors for winter rye $(*=$ winter wheat). $\mathrm{P}=$ net production, $r u=r y e, r i=$ weeds, $m a=$ underground parts. Figures are in $\mathrm{g} / \mathrm{m}^{2}$ except for the last column. For details, see text.

\begin{tabular}{|c|c|c|c|c|c|}
\hline Author & $\mathrm{P}_{\mathrm{ru}}$ & $P_{\mathrm{ri}}$ & $P_{m a}$ & $\mathbf{P}_{\text {tot }}$ & $\mathrm{P}_{\mathrm{ma}} / \mathrm{P}_{\mathrm{ru}+\mathrm{r}}$ \\
\hline \multicolumn{6}{|l|}{ Brau (1962) } \\
\hline Canada, moist & 640.00 & - & 140.00 & 780.00 & .22 \\
\hline$" \quad$ dry & 290.00 & - & 530.00 & 820.00 & 1.83 \\
\hline \multicolumn{6}{|l|}{ Herbich (1969) } \\
\hline Poland 1966 & 870.92 & 20.20 & 143.96 & 1034.12 & .16 \\
\hline " 1967 & 809.40 & 36.68 & 139.28 & 984.40 & .16 \\
\hline \multicolumn{6}{|l|}{ Kukielska (1973) } \\
\hline Poland I 1971 & 1123.17 & 52.76 & 231.10 & 1428.57 & .20 \\
\hline " II 1971 & 1148.38 & 65.62 & 229.04 & 1465.57 & .19 \\
\hline \multicolumn{6}{|l|}{ Wójcik (1973) } \\
\hline Poland 1969 & 885.36 & 75.78 & 175.20 & 1159.27 & .18 \\
\hline$n \quad 1970$ & 790.08 & 31.78 & 168.30 & 1006.89 & .20 \\
\hline \multicolumn{6}{|c|}{ Pasternak (1974)* } \\
\hline Poland & 1072.23 & 81.20 & 293.80 & 1537.03 & .26 \\
\hline Present results & 502.00 & 144.50 & 190.20 & 853.90 & .29 \\
\hline
\end{tabular}


an overestimation.

The root production figure obtained here by substracting the minimum biomass from the maximum was $190.2 \mathrm{~g} / \mathrm{m}^{2}$, giving a ratio of underground to above-ground biomass production of 0.29 . According to BRAY (1963), this ratio increases as moisture content decreases (Table 3).

The efficiency of above-ground biomass production in this field was $0.7 \%$ relative to total incoming solar radiation, as compared with the figure of $0.9 \%$ quoted by KAMINSKI (1970) for rye in Poland. Green biomass reached its maximum here about one and a half months after the peak in solar radiation (Fig. 3).

\subsection{The timing of local weed research}

Large-scale surveys of weeds in cultivated fields, e.g. the work of MuKUla et al. (1969) and RAATIKAINEN \& RAATIKAINEN (1975, 1979 a, 1979 b), often have to be simplified as far as the numbers of observations and samples collected are concerned, largely for reasons of expense. Where this is the case, the question arises of the correct timing of these events.

The most appropriate times for the determination of seeds in the soil are either early in the spring, before they germinate, or in the autumn, when the new seeds have fallen to the ground and some of those that are capable of germinating immediately have emerged
(KROPAC 1966).

In Finland sampling in the autumn also enables a count to be made of plants of the winter annual weed species that appear in such great abundance together with winter grain, but since the majority of weeds emerge in early summer, the beginning of June is a suitable time for observing the occurrence of both species and individuals. A much better measure of the interaction between grain and weeds than the number of individuals is nevertheless the biomass, the best time for assessing which is at the end of July, coinciding with the maximum weed biomass.

Particularly significant among the weed flora are the perennial species, which may account for a negligible proportion of the seeds in the soil but possess vigorous vegetative growth habits, which can best be quantified from underground biomass samples. Elymus repens is one of the most problematical longterm weeds affecting cultivated fields in Finland, and occurs in at least $39 \%$ of winter rye fields (RAATIKAINEN \& RAATIKAINEN 1979). In the present results it accounts for $21 \%$ of the maximum above-ground biomass. In this case its underground parts provide a more reliable guide to its growth potential than do the seeds found in the soil. Admittedly Hilli (1966) claims that its seeds have a germination rate of $94 \%$, so that they are capable of germinating rapidly, but they still make up only $0.11 \%$ of the total seeds in the ground.

\section{References}

Anıszewskı, T. \& Sıмолокı, P. 1094. Rikkakasvien siementen măără ja elinvoima eräillă MTTK:n kiertokoealueilla. Maatalouden tutkimuskeskus. Tiedote 22/84: $1-38$.

BrAY, J.R. 1963. Root production and the estimation of net productivity. Can. Jour. Bot. 41: 65-72.

Brenchley, W. \& Warington, K. 1930. The weed seed population of arable soil. I Numerical estimation of viable seeds and observations on their natural dormancy. J. Ecol. 18: 235-272.

Brenchley, W. \& Warington, K. 1933. The weed seed population of arable soil. II Influence of crop, soil

and methods of cultivation upon the relative abundance of viable seeds. J. Ecol. 21: 103-127.

Brenchley, W. \& Warington, K. 1936. The weed seed population of arable soil. III The re-establishment of weed species after reduction by fallowing. J. Ecol. 24: 479-501.

Buchlı, M. 1936. Ökologie der Ackerunkräuter der Nordostschweiz. Beitr. geobot. Landesaufname d. Schweiz, 19: 1-354.

Budd, A.C., ChepIL, W.S. \& Doughty, J.L. 1954. Germination of weed seeds. III The influence of crops and fallow on the weed seed population of the soil. 
Canad. J. Agric. Sci. 34: 18-27.

ERvio, L.-R. 1972. Growth of weeds in cereal populations. J. Sci. Agric. Soc. Finl. 44: 19-28.

ERvıO, L.-R. 1977. Rikkakasvien taimettuminen. Kasvinsuojelulehti 10: 29-32.

Ervio, L.-R. 1978. The effect of the sowing date and the density of winter cereals on weeds. Ann. Agric. Fenn. 17: $18-22$.

ERvio, L.-R. 1981. The emergence of weeds in the fields. Ann. Agric. Fenn. 20: 292-303.

Herbich, M. 1969. Primary production of a ryefield. Ekol. Pol. 18: 343-350.

HıLı, A. 1966. Juolavehnăn merkitys siementavarassa. Koetoim. ja Käyt. 23: 37, 39.

KAMINSKI, A. 1970. Absorption of solar radiation by a rye field (Secale cereale L.). Ekol. Pol. 18, 10: 243250.

KolK, H. 1962. Viability and dormancy of dry stored weed seeds. Văxtodling 18: 1-192.

Korsmo, E. 1930. Unkrăuter im Ackerbau der Neuzeit. 580 pp. Berlin.

KROPÁĆ, Z. 1966. Estimation of weed seeds in arable soil. Pedobiologia 6: 105-128.

KuKIELSKA, C. 1973. Primary productivity of crop fields. Bull. Acad. Pol. Sci. 21: 109-115.

MukulA, J. 1964. Rikkaruohot ja niiden torjunta. 140 p. Helsinki.

Mukula, J., RaAtikainen, M., Lallukka, R. \& RaAtikalNEN, T. 1969. Composition of weed flora in spring cereals in Finland. Ann. Agric. Fenn. 8: 59-110.

PaAtela, J. \& Ervio, L.-R. 1971. Weed seeds in cultivated soils in Finland. Ann. Agric. Fenn. 10: 144152.

Paldanius, E. \& Sıмолокı, P. 1984. Rikkakasvien siementen määră ja elinvoima Satakunnan ja Etelä-Pohjanmaan tutkimusasemien maanäytteissä. Maatalouden tutkimuskeskus. Tiedote 22/84: 39-56.

Pasternak, D. 1974. Primary production of field with winter wheat. Ekol. Pol. 22: 369-378.

Pessala, B. 1978. Juolavehnän ja leskenlehden torjunta. Kasvinsuojeluseuran Julk. 58: 24-26.
RaAtikainen, M. \& RaAtikainen, T. 1975. Heinănurmien sato, kasvilajikoostumus ja sen muutokset. Summary: Yield, composition and dynamics of flora in grasslands for hay in Finland. Ann. Agric. Fenn. 14: 57191.

RaAtikainen, M. \& RaAtikainen, T. 1979 b. Syysrukiin perustaminen, hoito ja rikkaruohojen ekologia. Summary: Establishing and management of winter rye and the ecology of weeds in rye fields. J. Sci. Acric. Soc. Finl. 51: 432-479.

RaAtikainen, M. \& RaAtikainen, T. 1983. Syysvehnän viljelystă ja sen vaikutuksesta rikkaruohoihin Suomessa. Summary: Survey on cultivation of winter wheat and its effect on weeds in Finland. J. Sci. Agric. Soc. Finl. 55: 385-423.

RaAtikainen, M., RaAtikainen, T. \& Mukula, J. 1979 a. Weed species, frequencies and densities in winter cereals in Finland. Ann. Agric. Fenn. 17: 15-142.

Raatikainen, M., RaAtikainen, T. \& Mukula, J. 1985. The biomass of weeds in winter cereal fields in Finland. Ann. Agric. Fenn. 24: 1-30.

RaAtikainen, M., RaAtikainen, T. \& Tinnilā, A. 1971. Rikkakasvit ja niiden torjunta. Kasvinsuojeluseuran Julk. 46: 1-108.

SALONEN, M. 1949. Tutkimuksia viljelykasvien juurten sijainnista Suomen maalajeissa. Summary: Investigations of the root positions of field crops in the soils of Finland. Acta Agr. Fenn. 70: 1-91.

Tómàlä, T. \& RaAtikainen, M. 1976. Primary production and seasonal dynamics of the flora and fauna of the field stratum in a reserved field in Middle Finland. J. Sci Agric. Soc. Finl. 48: 363-385.

van der Vegte, F.W. 1978. Population differentiation and germination ecology in Stellaria media (L.) Vill. Oecologia 37: 231-245.

Wehsarg, O. 1912. Das Unkraut im Ackerboden. Arbeiten Dt. Landwirtsch. Ges. 226.

WoJCIK, Z. 1973. Productivity of a sandy ryefield. Ekol. Pol. 21: 339-357.

Ms received January 22, 1990 


\title{
SELOSTUS
}

\section{Ruispellon kasviston vuodenaikaisvaihtelu ja tuotos}

\author{
Päivi Halinen ja Mikko Raatikainen \\ Jyväskylän yliopisto, Biologian laitos, \\ Yliopistonkatu 9, 40100 Jyväskylä
}

Tutkimus on osa maanlaajuista syysviljojen rikkakasvitutkimusta. Tämă osatutkimus suoritettiin Jyväskylăn maalaiskunnassa, missă 1.4 ha:n suuruisesta ruislohkosta tutkittiin 0.3 ha:n alue. Maaperăn rikkasiemenistőstă otettiin keväăllä kahdeksan näytettä. Maanpäällisistä ja -alaisista kasveista otettiin näytteet seitsemän kertaa kasvukauden aikana.

Maaperän $20 \mathrm{~cm}: n$ muokkauskerroksen rikkasiemenmäärä oli $93965 \mathrm{kpl} / \mathrm{m}^{2}$. Ne kuuluivat ainakin 36 lajiin. Kevăt- ja syysyksivuotisten lajien osuus siemenistössă oli $89.6 \%$. Kasvukauden aikana muokkauskerroksen kokonaissiemenmäărăstä taimettui $0.3 \%$.

Maanpaaallisen kasvillisuuden vallitsevat lajit olivat ruis ja juolavehnä. Muiden rikkaruohojen biomassan kehitys

jăi heikoksi rukiin ja juolavehnän voimakkaan kilpailun takia. Taimettumista sen sijaan tapahtui varjostuksesta huolimatta ja muiden rikkakasvien osuus kokonaisyksilömäărästă kohosi maksimiajankohtana (12. elokuuta) $14.5 \%$ :iin.

Maanpäăllisen elăvän biomassan maksimi, $614 \mathrm{~g} / \mathrm{m}^{2}$ oli 12. elokuuta. Maanpäälliseksi kokonaisnettoprimaarituotokseksi saatiin $664 \mathrm{~g} / \mathrm{m}^{2}$. Rukiin osuus tuotoksesta oli $78 \%$, juolavehnăn $21 \%$ ja muiden rikkaruohojen $1 \%$. Maanalaisten kasvinosien nettotuotos oli $190 \mathrm{~g} / \mathrm{m}^{2}$. Maanpäällisten ja -alaisten kasvinosien ja karikkeen yhteenlaskettu nettotuotos oli $854 \mathrm{~g} / \mathrm{m}^{2}$. Energiasisăllöltaaăn se vastasi $0.7 \%$ kasvukauden aikana pellolle tulleesta auringon săteilyenergiasta. 